\title{
Visual Grammar of Ramayana Story Reliefs of Prambanan Temple
}

\author{
Asep Deni Iskandar ${ }^{1,2^{*}} \quad$ Rustopo $^{1} \quad$ Dharsono $^{1} \quad$ Timbul Haryono $^{1}$ \\ 1.Postgraduate program, Institut Seni Indonesia (ISI) Surakarta, Jl. Ki Hajar Dewantara No. 19 Surakarta, \\ Indonesia \\ 2.Department of Desain Komunikasi Visual, Universitas Widyatama, Jl. Cikutra No. 204 B Kota Bandung, \\ Indonesia
}

\begin{abstract}
Ramayana story reliefs in Prambanan temple complex is still a concern until now. Ramayana reliefs for researchers are considered information in visual form which narrates Ramayana epic. In visual context, Ramayana reliefs are illustrations transformed from a sacred book. The story is quite long in every part of the sacred book, thus the scenes were selected in order to be visualized on each panel. The visualized scenes on each panel and the arrangement of the transition of the scenes from panel one to the next panel made the reliefs form a complete Ramayana story. The series of scenes arranged to form the story, in the context of modern visual, resembles a film. The reliefs reading thus are done by using modern visual or aesthetic perspective. The way of characteristic drawing on reliefs is very different from the way of modern drawing. The way of characteristic drawing used by the past sculptors shows the arrangement of objects and characters on each scene, either on the panels or in the transitions between panels. In arranging each scene, the sculptors used certain visual grammar. Thus, visual grammar is used in this research to examine Ramayana story reliefs.
\end{abstract}

Keywords: visual grammar, Ramayana story reliefs, transformations, scenes

DOI: $10.7176 / \mathrm{ADS} / 72-04$

Publication date: April $30^{\text {th }} 2019$

\section{Introduction}

Ramayana story reliefs of Prambanan temple are a manifestation of culture of the past which can be seen based on a number of perspectives. These perspectives are based on the approach that will be used by the community and researchers in present time. Ramayana story reliefs can be seen as a media of communication of the community at the time being, a form of expression of fine art, and symbolic system. Media of communication becomes the basic approach in understanding the form of expression of fine art, which then gives an understanding of the symbols sculpted on the reliefs of the temple.

The symbols sculpted on Ramayana story reliefs contains guidance, therefore the messages could be delivered to the supporting community. It can be said that Ramayana story reliefs are cultural artifacts which contain knowledge, teaching, and spiritual value. The story reliefs at the temple, besides present aesthetics value, also has spiritual meaning presented in symbolism of art corresponding to its religious duty (Yudoseputro 2008, 71). Story reliefs then became important to deliver the teachings applicable at the time being, for transferring massages orally only would issue distortion. The knowledge and the teachings sculpted on the temple walls became a smart book which will be delivered to the next generation. The knowledge depicted on the temple reliefs became integrated units, so behavior, social order, and belief, aesthetic values, symbolic and aspects of storytelling are related to each other (Setiawan 2012, 131; Tabrani 2005, 20).

Story reliefs which function as a media of information delivery must be readable by public. The sculptors who made the story reliefs did not rely on their sculpting skill only, for they had to be able to convey information on each relief panel. In this context, there appeared a connection between the sculptors (tatsaka) and the temple reliefs. The sculptors conveyed contents/information on Ramayana story reliefs by harmonizing the element of the object and the visual grammar. The uniqueness of the temple reliefs made by using the sculptors' visual grammar are not fully revealed up to now.

This research aims to reveal the visual grammar applied to Ramayana story reliefs on Prambanan Temple. Visual grammar is used as a tool to examine the drawing system in the $9^{\text {th }}$ century, including the arrangement of each object shown on each relief panel. The drawing system used by the sculptors in the past had used the ways that works nowadays combined with traditional ways. The combination of the drawing way applied on each panel results in picture telling. This research is also a very basic to be conducted to position the system of the characteristic drawing on Ramayana reliefs in the discourse of development of fine art knowledge, design, and recording media.

\section{Methodology}

This research is categorized as a qualitative research, which specifically discusses about visual grammar on Ramayana story reliefs. Qualitative method was chosen to explain and to explore visual grammar and its 
application on Ramayana story reliefs, including the complexity following. Data collection was conducted to both primary and secondary sources. Data collection methods used were direct observation, interviews, and literature study. Direct observation was used to explore material data (artifacts) required to answer the research problem of visual grammar on Ramayana story reliefs of Prambanan temple. Observation was also used to examine physical data of each selected relief panel. The relief panels were selected based on certain criteria, they are ones which show impression of motions of each scene. Interviews were conducted to several informants, they are: bystander, researcher, and public figure. Interview aims to reveals the drawings on the reliefs. Literature study was used to collect information related to this research as well as data of previous similar research, including to get supporting data about visual grammar analyses of Ramayana story reliefs. Data were analyzed continuously as of the process of data collection started up to the completion of the data collection. The result of data analyses was then interpreted and described, subsequently a conclusion was withdrawn.

\section{Results and Discussion}

Temple reliefs used as a media of communication must related to the aspects in visual language. Like a good written language arranged/composed by using its grammar system, the objects on the reliefs were also arranged by using the guideline of its own grammar that is drawing or visual grammar. The formation and the arrangement of each object need to use appropriate grammar to be able to carry and to deliver messages as expected. In the linguistics field, words and sentence somposition are the aspects used to communicate. Adisasmito (2007) classified aspects of communication used in visual language that are elements in fine art such as configurations, colors, lines, textures, space, and volume which are combined.

In written language, there are words and written grammar, while in visual language there are images and its grammar as its equivalent. Tabrani (2005) stated that, "images include wide meaning, that are visible images and imaginary images, while wimba (image; image object) is for visible images". The term "wimba" itself comes from "imba" which is from Kawi (Jawa Kuno - Ancient Javanese) language, which means a character or a form (Yuliman, 2001). "Wimba" can also be called as an image of a thing or an object, and an image cannot be separated from grammar as a content construction of the isi wimba (image content) and its cara wimba (image way). The term object in a relief is similar with the argument of Yudoseputro $(2008,78)$, that the depiction of the story characters figure as the main objects which are realistic is different from the depiction of the story background of expression in stylistics form of the same plane. Isi wimba (image content) is the item described from a real object or an image of human imagination, while cara wimba (image way) is how the content of an object is shown in order to be able to carry a message (Tabrani 1991, 22). It is similar with written language which contains words, the sentences in a readable interesting writing which at the same time can carry messages are a result of the construction of the words that compose the writing. The arrangement is based on a valid grammar and follows standard rules. As a language, the arrangement of various isi wimba (image contents) and cara wimba (image way) in an image which aims to be able to tell stories in the context of visual language is called in the term tata ungkapan (grammar of visual language).

The arrangement of basic elements shown in Ramayana story reliefs forms an offering of visual aesthetics. Each element and object in the image are arranged in certain order to form a story. Storytelling aspects are the characteristic shown in reliefs by means of the characteristically drawing way done by the sculptors. Characteristic drawing used on the reliefs of Ramayana story can show different space and time in one panel. Prasetya $(2016,302)$ expressed, ".. in one frame of relief the story depicted does not only happen in the same space and time but also in different space and time.".

\subsection{Temple Reliefs and Drawing System}

Communication artifacts or visual works are manifestation of media of information. Visual works as well as temple reliefs were made into media for message delivery, hence transfer of information occurs. Visual works or communication artifacts became symbols in visual form used to represent mind or feeling. Images in visual works are communication subjects which would like to be delivered by the creators to public by using certain system. Tabrani $(2009,13)$ divided those imges systems into two categories, they are Space-Time-Plane (STP) system and Naturalistic-Perspective-Moment opname (NPM).

STP is a model of visual communication which prioritizes story representation and shows plural space and time. Transfer of information is packaged in the context of attita-nagatta-wartamana (past-now-later) as a characteristic of a story (Setiawan 2012, 162). The artifacts of STP system in Indonesia can be found on prehistoric rock pictures, tradistion drawing as in Ramayana story reliefs of Prambanan or Wayang (Indonesian traditional puppet performance) Beber, and the drawings by children. In Ramayana story reliefs of Prambanan analyzed in this research, it is shown that the images are in form of various scenes in different space and time but presented in one plane (panel). In other words, the depiction on the story reliefs of Ramayana becomes a sequence which consist of various scenes. STP system is used to present time spell in the story reliefs, thus the overall visual is not seen based on the size of the drawing plane, without neither frame nor perspective. The 
absence of perspective in the reliefs is in line with the explanation described by Yudoseputro $(2008,78)$ that: "the expression of space based on perspective guideance in Europe fine art tradition was not known in Indonesian fine art. The absence of perspective ways occurs due to each object in a single image is depicted in various appearance, time, and distance. The depiction makes Ramayana reliefs have a very strong story telling ability albeit without text.

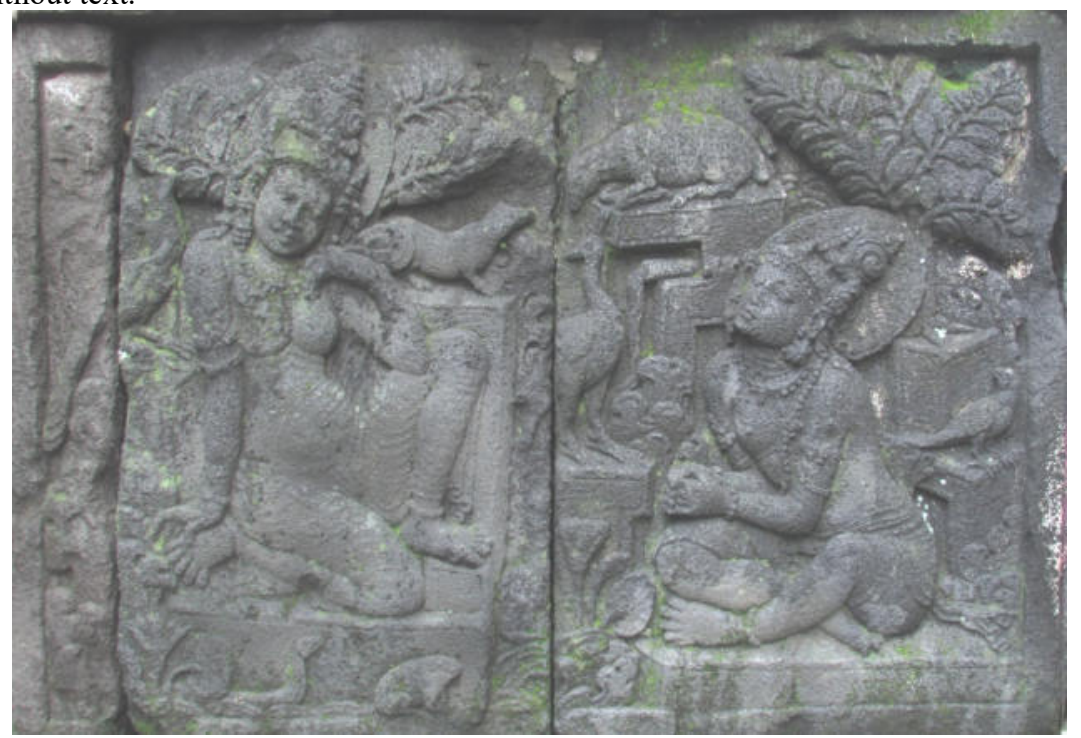

Figure 1. Relief Panel 18 of Brahma temple. Laksmana explains to Sinta about the order of Rama to banish to the woods. This relief shows naturalistic drawing combined with more dominant STP images order. (Source : Iskandar, 2017)

As the opposite of RTP visual communication model, it is NPM which depicts an event in a single space and time. The drawing system NPM considered as more modern gained justification and became more steady along with the invention of photography camera. The characteristics of camera lens is affecting images, hence the space and time moving are stopped in one time, one space, and one direction. The image produced is a still picture which confines the space and time in a frame, and shows a Naturalistic-Perspective-Moment opname.

The drawing techniques of STP and NPM that had developed is a very basic human ability encouragement. STP images order which combines with NPM can be seen on figure 1, albeit the tendency goes to.STP. NPM depiction can be seen on the relief, albeit perspective is absent. NPM images order are shown in a naturalistic way on each object or the characteristic being told, while single space and time (moment opname) are depicted on the panel.

\subsection{Visual grammar of Ramayana story reliefs}

Examining the appearance of Ramayana story reliefs is different from the ways conducted to aesthetic study, albeit both of them use the same elements. The point that makes the difference is the study of appearance does not conduct appraisal like the tendency of aesthetic study, albeit aesthetic sensitivity needs to be possessed in the study of appearance (Setiawan 2010, 185). In the study of appearance the points analyzed are the characteristics of the forms of the images or temple reliefs, for instance dynamic format is depicted in a way of curved body of a human shooting by using archery. According to the way of drawing as explained earlier, relief analyzing is then not the way of drawing known in visual art. A way of drawing is a way of information depiction with certain criteria, for example: naturalistic way, stylistic, decorative, etc. This way of drawing relates to visual grammar for each relief panel presents some information in form of stories or various events.

As explained, visual grammar is a way of arranging or placing various image contents (object), including image ways of the object and the direction of seeing so the image can tell a story in a drawing plane. Visual grammar can be interpreted as composition arrangement of each object or making use of inter image planes. Therefore, the image does not only look harmonious but is also able to express messages which want to be delivered. For instance, the depiction of the main object with centered composition has the meaning that the center of attention of the image is placed on the object in the middle. The making use of image way in one panel of temple reliefs is hence called Inner Visual Grammar (Tata Ungkapan visual Dalam - TUD). When the image way is used to arrange images on a sequence of images, as well as Ramayana story reliefs which in total consist of 54 panels and are scattered in Shiva and Brahma temples, it is then called Outer Visual Grammar (Tata Ungkapan visual Luar - TUL). 


\subsubsection{Inner Visual Grammar [TUD]}

TUD is used in examining Ramayana story reliefs of Candi Prambanan to figure out the arrangement of each object drawn on a panel. Ramayana story reliefs albeit are presented in a form of sequences of relief panels related each other (serial panel), each of the relief panel has its own story. The story presented one a panel is not only one scene but also consists of several story scenes. The story scenes depicted on each panel relief can be read by public based on the arrangement of inter objects. The objects presented on the panel plane are arranged in a certain way so that a background layer is configured, and all of the scenes can be told. In other words, the sculptors at the time being had used a way of background layer as well as in digital processing which uses a software such as Adobe Photoshop.

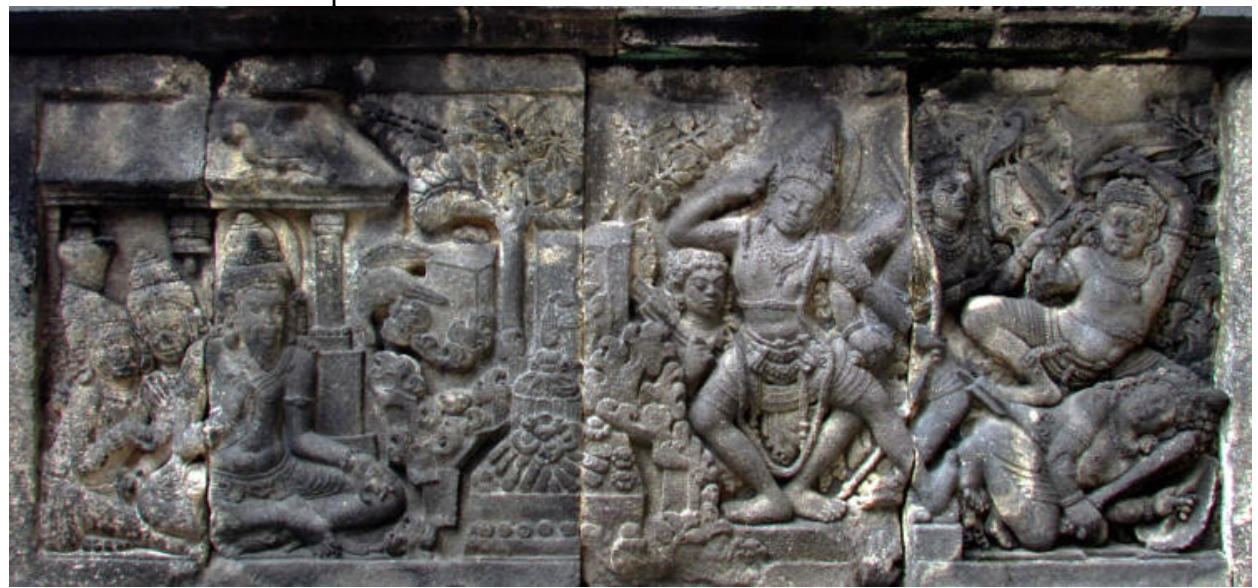

Figure 2. Relief Panel 4 of Shiva temple tells about Rama and Laksmana who helped rishi Vishwamitra to quell the rakshasa, the deamon in Hindu also called maneater, who always ruin his hermitage. (Source: Iskandar,

Relief sculptors have the capability to set each object on each limited panel. The arrangement of each object on a media in modern drawing system is known as the term "composition". The setting of each object, which in the context of NPM is considered unusual, can apparently show an impression of different space and time. The difference of space and time depicted in one panel also gives an impression of motion. The impression of motion seen on the relief is shown by ways of the depiction of several different scenes. Different space and time scenes, for instance, can be seen on panel 4 (see figure no. 2), located on the langkan (fence) of Shiva temple. This panel depicts three different scenes with different space and time. The first scene, occurred on the left side of the panel, shows rishi (sage hermit) Vishwamitra and the hermits are doing an offerings [religious offerings] ceremony. The second scene shows the event of Rama and Laksmana killed Rahu depicted on the right side of the panel at the background layer. The next scene occurs on the front layer, Maricha (Mareecha) was hit by an arrow released from the bow of Rama.

The other way used by the reliefs sculptors to depict the impression of motion that is by drawing twin way (plural images). The twin way is done by drawing the same character repeatedly on a panel so that the character can be seen as if budging, or the story scene can seem to be different. On several panel reliefs of Ramayana, twin way can be seen on characters such as Rama, Laksmana, or Sita who appear two or three times in one panel. The character depicted several ways in a panel can be seen on panel 16 at Shiva temple.

Panel 16 shows the same character is depicted on three scenes which present different place and time. On the first scene of the relief panel, Laksmana asked by Rama to look for water is giving the water to Rama sitting in thirst. The viewer is directly asked by the sculptor to see the water being given by Laksmana to Rama. Laksmana in the panel is depicted holding a bumbung (a water container made of bamboo) in a squat down position. In the context of film, the depiction of the panel shows the presence of a cut to cut way. The story cut is when Rama asks Laksmana to look for water because he feels thirsty after having a long journey while looking for the presence of Sita. The depiction on the panel was straightly conducted on the scene when Laksmana gives the water he collects into a strip of bamboo. In the middle of the panel, it is shown the scene of Laksmana squats down and collects water which flows from the foliage. The water comes from the tears of Sugriva crying in the tree. Laksmana, who does not know that Sugriva is in the tree, was depicted as one whose head is looking down and paying attention to the water getting into the container. On the right side of the plane, the last part of the story in this panel, the meeting scene among Rama, Laksmana, and Sugriva is depicted. The repeatedly depiction of the same character is meant to show the move of space and time, or the impression of motion experienced by the character. The observation result of the drawing way on relief panel 16 is shown on figure 3 . 


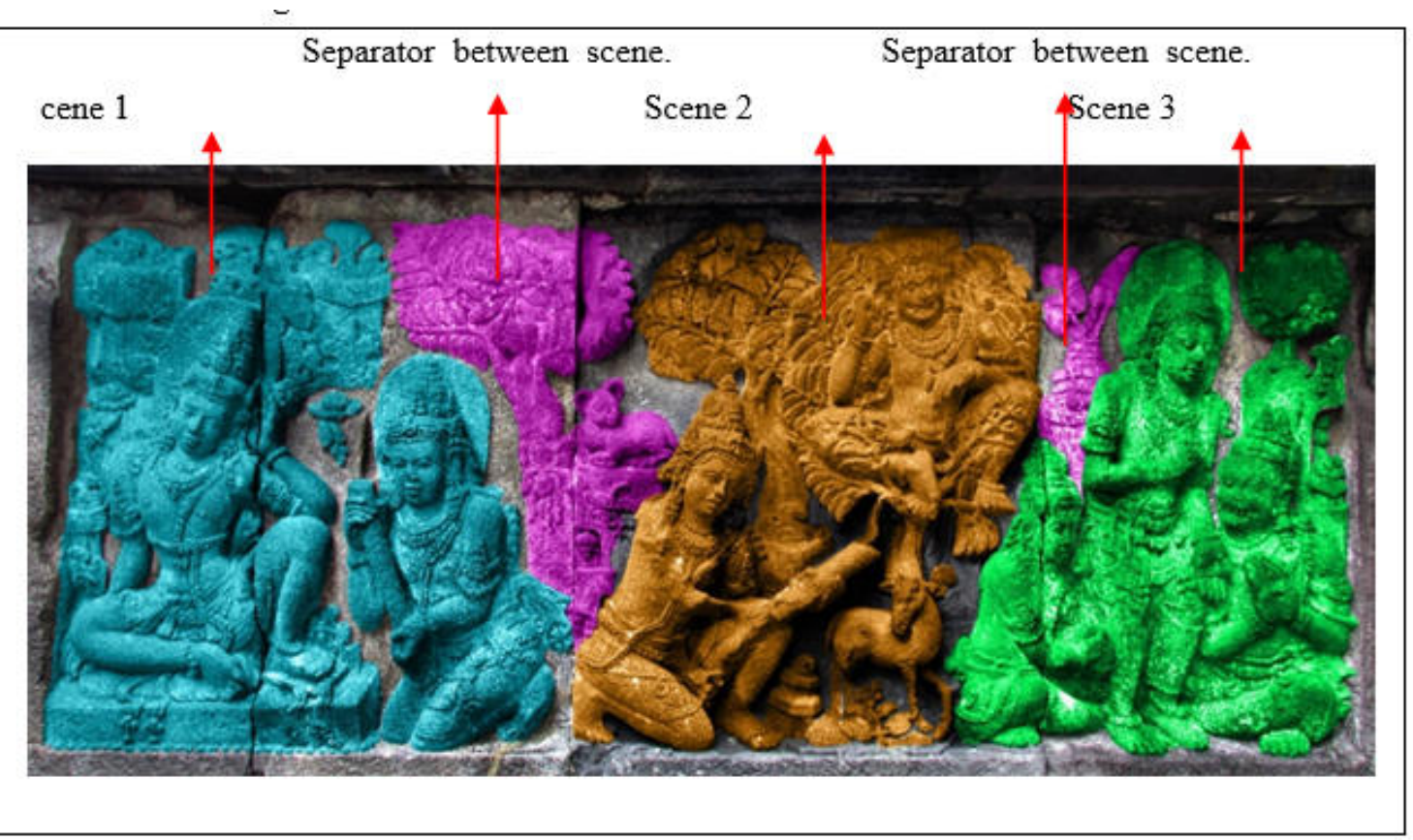

Figure 3. Relief Panel 16 of Shiva temple, three scenes in one panel that narrate the process of the meeting among Rama, Laksmana, and Sugriva.(Source: Iskandar, 2017)

It is interesting to examine, the scenes arranged in panel 16 especially the order of the position of the first and the second scene. The scenes of different occurrence in the panel are depicted by showing a number of layers and characteristics of space and time in each scene. As previously explained, the first scene depicts Laksmana giving the water to Rama while the second depicts Laksmana getting the water. When the analyses refers to the rules of the direction of seeing the story from left to right, then the first scene depicted in the panel is the process of taking water which then continues to the scene of giving water. However, the sculptors did not depict the scenes as explained previously but in reverse. The position of the reverse scenes indicated that the sculptors at that time had used the method used in film namely flashback on a screen (Tabrani, interview: November 11 2018). The same thing was also said by the observer Setiawan in an interview (July 07 2018), "the relief sculptors in Prambanan temple tried to make a method the story continues in each panel, and the whole story was packed again like making a movie, one of the was using flashback."

Flashback is used to narrate Rama's question to Laksmana about the source of the water because the water taste salty. Laksmana then told that the source of the water is from water droplets in a tree. Rama's curiosity of the taste of the water that made him look for it. The water drunk by Rama is apparently from the tears of Sugriva, entangled in roots, collected in a piece of bamboo by Laksmana (Hermanu 2012, 43). Rama then saved Sugriva, and a dialogue to help each other takes place.

The visual grammar to depict different space and time in each scene is shown via the gestures by each character. Each character's gestures look dynamic, for instance Rama sitting waiting for water from Laksmana, Laksmana squatting to collect water, Sugriva in the tree, and the conversation among those three characters. The gestures are the aspects that the ones who see can easily recognize each of the characters (visible characteristics). The visible characters from the objects and the figures in the relief panel are depicted from a fit angle. When the panel is observed, the depictions are not from one angle only but from various angles. The width of the leaves in the trees that grow in the forest and in the area in which Sugriva is entangled in roots are depicted from the upper side angle, so the shape and the width of the leaves can be clearly seen.

The differences of space and time depicted are strengthen by depicting each object with different scales, there are objects enlarged and there are ones diminished. The different scales of the depiction used in the panels is intended to show all story in a limited space of the panel plane. The different scales used make the depiction in the relief peculiar.

The tall and large trees in the relief are depicted in smaller scale, thus they look intact. The body of Sugriva entangled in roots is actually at height, so he cannot be seen by Laksmana collecting water. For Sugriva's body to be able to be seen clearly and thus the story can be conveyed, therefore the scale of the depiction was enlarged. The depiction scale enlarge can also be seen on the object of the bamboo blade used to collect the water, deer, and flowers behind Rama sitting. To show the life in the forest, the lion behind Laksmana collecting 
water is also depicted by using minimized drawing scale. The drawing uses minimized scale on the relief because the lion is not the main object that want to be told, for the purpose of the drawing is to describe the environment in the forest. Drawing scale of the object minimized and enlarged, according to Ayuati (interview: April 2 2018), is the result of the consideration of the sculptors in their attempt to arrange all the objects in a limited space and to collate several scenes in one panel so that all the stories can be conveyed to public. In other words, the drawing conducted by using the scale to the objects that are enlarged or minimized is not without any reason for it is the attempt of the sculptors in telling the story by way of reliefs.

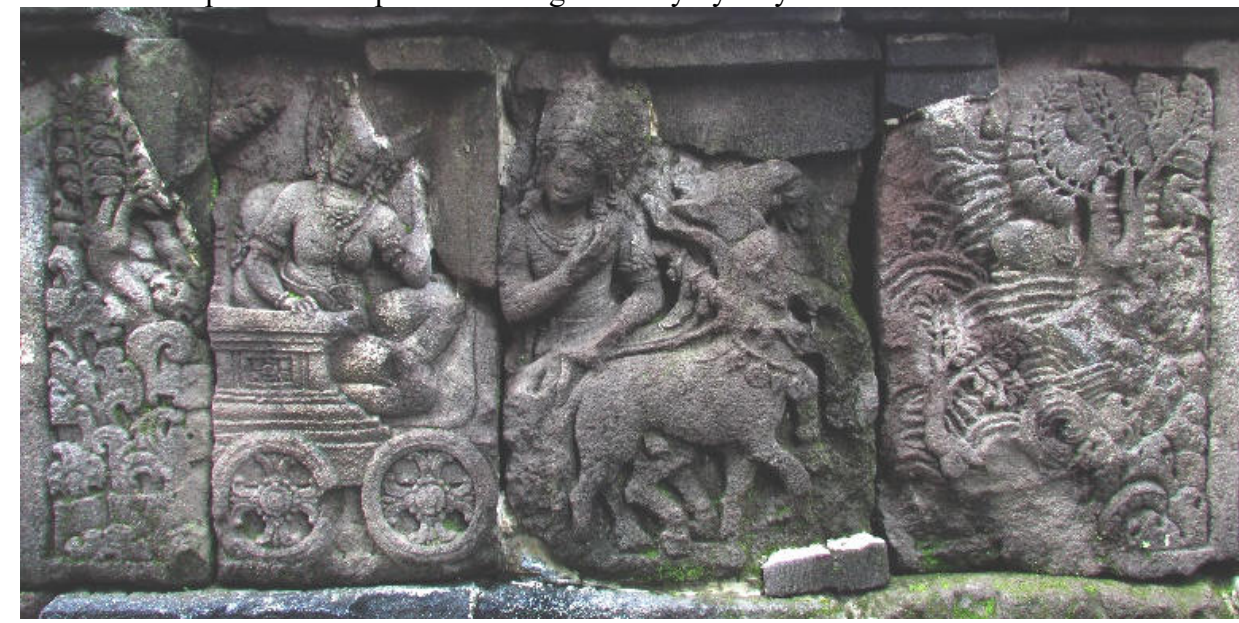

Figure 4. Panel 17 of story relief Ramayana in Brahma temple (Source: Iskandar, 2017)

The impression of the motion depicted in the relief panels is not always made by way of drawing the scene series. It can be said that the panel of relief story of Ramayana existed in the two temples can show the impression of the motion albeit it is shown in only one scene. The impression of motion is shown through the motion of the body of an object albeit the object is seen as motionless or by freezing to a moving object. This is almost similar with the depiction achieved by a camera which records a moving object, specifically the object is stopped for a moment and it then becomes freezing. The object that the motion is frozen in the relief is created by presenting motionless object and moving one at the same time so all of the story can be conveyed. Such a drawing way can be seen, for instance, in panel 17 of Brahma temple.

Panel 17 in Brahma temple depicts the scene of Sinta delivered by Laksmana towards the exile forest by golden chariot. Sinta, who would be exiled, is placed behind sitting in the chariot. Laksmana, who delivers Sinta, is placed in the front showing himself as the driver of the golden chariot. Laksmana being the driver of the golden chariot was depicted as his body from his waist to the upper part partly covered by the body of the horse. The depiction made in this panel 17 shows the efforts of the sculptor to explain all scenes in the story, so that all objects were depicted clearly. Laksmana, in the panel, is shown on an enlarged scale to assert that he is the important figure in the story scene. Laksmana in the scene is asked by Rama to exile Sinta to the woods.

Visual grammar on the panels to depict all occurrences on limited plane is applied by using scale of depiction on the objects. The horse was depicted on a reduced scale, thus it looks smaller on the panel. The horse used to pull the golden chariot must be strong and big but it looks smaller and shorter on the plane, which in reality is like a pony (Subarno, interview: April 2 2018). The strength and virility of the horse was depicted by the sculptor by enlarging the penis part. If the horse is depicted proportionally, its penis should look smaller than its body. Another enlarged object can be seen on an animal with its head that appears from the density of the trees. As for the golden chariot ridden by Sinta, the chariot was depicted in reduced scale. The golden chariot was depicted as a narrow small one instead of big and completed with the space for the driver which was not depicted clearly (Susetyo, interview: April 1 2018). The lash and tall trees were depicted on reduced scale, with its density that looks clear enough. The lushness of the trees shown on the panel explains a wilderness forest, albeit it looks less. The trees depicted this little is the representative of the many trees in the forest.

The golden chariot located in the middle of the jungle as depicted on the panel creates a story scene. The scene of the story depicted by the sculptor was by stopping the moving chariot for a moment. The moving chariot albeit looks unmoved still shows the impression of dynamic motion. The visual grammar that shows the impression of motion on the panel is presented by the horse pulling the chariot and the postures of other objects. The gestures of several objects look dynamic for instance the moving horse, the head of the horse heading up, and the faces of the two characters. The gestures of the two characters depicted on the panel explain the situation at the time. The face of Laksmana depicted as if he is looking toward Sinta shows that a dialogue between them is taking place at the time being. His left hand holding the bridle and his sturdy body facing toward the audience assert that Laksmana was being the driver of the golden chariot at the time being. The gestures depicted toward 
Sinta give the impression of a sad expression because she heard the story from Laksmana about her exile to the wilderness forest (Susetyo, interview: April 1 2018). The gestures of each object explain the presence of the impression of motions albeit the objects look unmoved. This explanation is in line with Subarno that said "objects depicted on the panel look still but giving an impression that there are motions" (interview: April 2 2018).

3.2.2. Outer Visual Language (TUL)

The Ramayana story reliefs of Prambanan temple is a story sequence of each panel. The scene in one panel continues to the next panel, with different story or scene. Using the film analogy, one relief panel consists of a scene which depict the smallest part of the overall story. The scenes in each panel are related to the other relief panels. The story sequence visualized in each panel (sequenced panels) gives a complete story. To understand the information about the story sequence in the Ramayana reliefs of Prambanan temple, then it is Outer Visual Grammar (TUL) used. TUL is a way used by the sculptors in makin differences between the Inner Visual Grammar in one panel and the next panels (Tabrani 2012, 206). Such way was used to make the separated scenes in each panel give a form of a whole story. TUL was used to examine the story reliefs of Ramayana by understanding the arrangement of each relief panel in the story sequence.

The panel serials of Ramayana story reliefs in both temples make audiences able to read in sequence by getting in and out through the main gate at the East. The shift between both temples shows the continuity of the story, that the story is not finished in Shiva temple only but continues to Brahma temple. This continuity of the story in the context of modern drawing system is shown by fade in, fade out, and fade from. Fade in can be read by the audiences twice i.e. in the first reading of both temples. Fade from can be seen by the audiences when they leave Shiva temple and head to Brahma, that is when they are asked to have a short break from the reading of the story presented on the panel reliefs. Fade out is obtained from the reading of the final story of both temples.

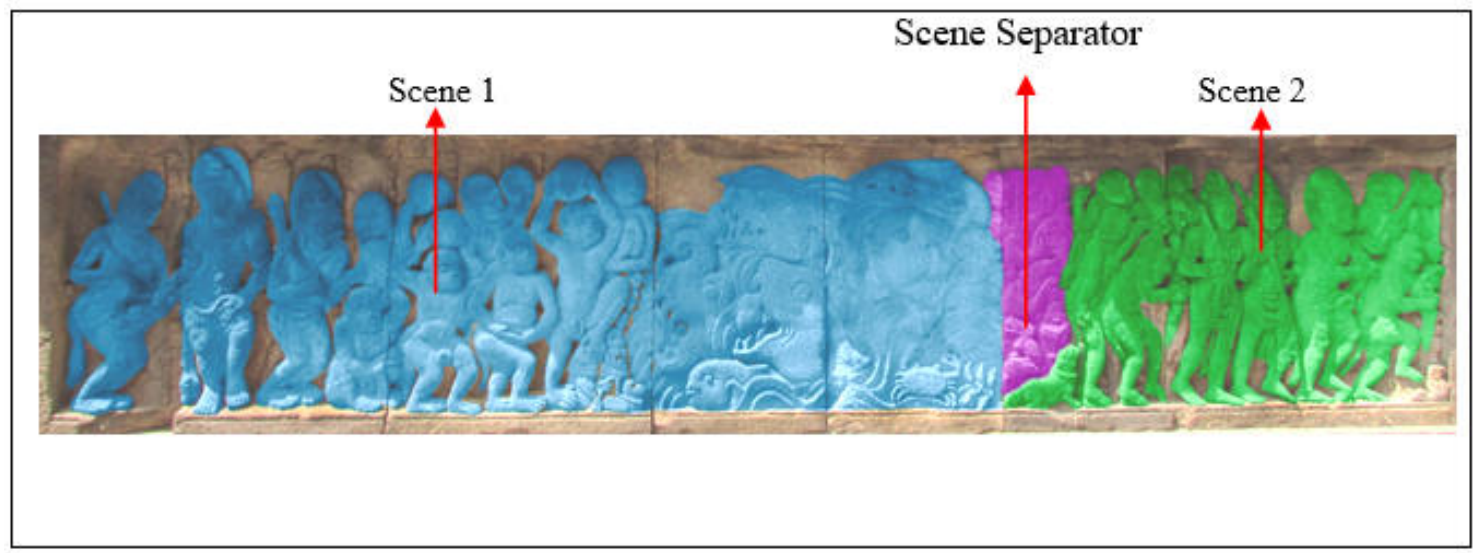

Figure 5. Panel 24 of Ramayana story relief in Shiva temple about the making of the bridge and the crossing of Rama's troops to Alengka.(Source: Iskandar, 2017)

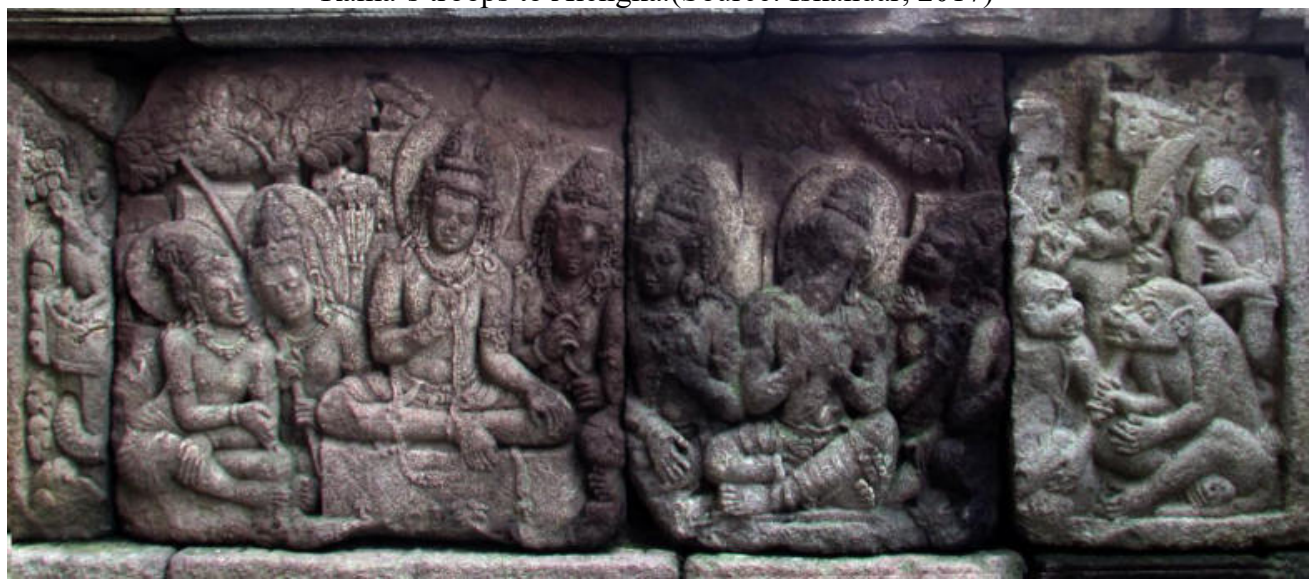

Figure 6. Panel 1 that is about the scene of the negotiation among Rama, Laksmana, and Sugriwa who manages the stratagem to attack Alengka. (Source: Iskandar, 2017)

The story of Ramayana presented on two different temples sums up the description of the greatness of the architects and the sculptors at the time in choosing the scenes to be visualized. It can be seen from the scene 
selection on panel 24 which becomes the end of the the first round of the story in Shiva temple. The second round of Ramayana story is continued on panel 1 in Brahma temple (figure 6). The story scenes selected on both panel are ordinary events which seem flat, instead of scenes of conflict. The depiction of flat scenes on the two different panels aims to show the continuity of the story, made by using fade in and fade out (Setiawan, interview: July 19 2018). Both of the fade techniques used as a transition in a film denotes the Outer Visual Grammar which presents the occurrence of the shift of space and time, that is from panel 24 of Shiva temple to panel 1 of Brahma temple.

Fade out on panel 24 (figure 5) is presented on the second scene which located on the right side of the panel. By way of fade out, the audiences can feel as if they are asked to enjoy the story scene of calm atmosphere first. The story scene depicted is not the climax scene or hubbub, but the tension (which gets) lowered (Setiawan, interview: July 19 2018). When it is connected to the story which continues to Brahma temple, the audiences are asked to walk on the bridge and to cross to Brahma temple, in which the audiences then read the continuation of the story stopped previously. In other words, this crossing can show sign system in the temple reliefs. The scene of this crossing can also denote that the sculptors of the temple reliefs had used the nowadays film technology by using transition effects such as fade out, the transition effect fade from that is when the audiences walk down the stairs of Shiva temple and out to move and to walk up to Brahma temple, and the last one namely fade in presented by getting into the next scene on panel 1 . When viewed more closely, both scenes in the last panel 24 of Shiva temple and panel 1 on Brahma temple are scene selection, so that the continued story can be read by the audiences (Persada, interview: November 2 2018). Scenes selected on the last panel of Shiva temple and the first of Brahma thus becomes the determinant of the continuity of the story.

\section{Conclusion}

Visual grammar on relief panels of Ramayana story is an organizing of objects presented on limited drawing plane, hence the image looks peculiar when it is seen through the perspective of NPM or aesthetics principles. In the context of characteristic drawing system (STP), the peculiar drawing is considered reasonable because the important aspect is the story that the sculptors wanted to convey. The story presented is not in form of one scene on one panel only for it can also be presented in form of several scenes depicted on one panel. In other words, the limited drawing plane does not limit the sculptors to depict many occurrences or scenes. The objects depicted are arranged in such a way by using drawing scale of objects, there are reduced and enlarged. Drawing scale on enlarged objects becomes different with reality. Object depicted by enlarged scale aim to state that the object is important, explain location, or bring certain atmosphere.

The objects arrangement on a panel can give a dynamic impression albeit the objects depicted are unmoved or frozen. The impression of motion is visualized by way of repetitive drawing of the same character. The appearance of the same character in every scene on a panel shows the shift space and time. The differences in the scenes are confirmed by depicting different gestures. The depiction either on a panel or on serial panels shows the greatness of the sculptors in the past to tell stories. The story reliefs which consists of 72 panels in total, located at two different temples, thus form a complete story of Ramayana epic.

The series of the stories can be seen by audiences walking and moving from one panel to the next. The story scene which shows the impression of motion, including the move of space and time between two different panels, assert that the nowadays way of drawing had been used at the time. The way of drawing can be seen on the pattern of background layer as well as in digital imaging of photography or by transitions of scene shifts used in film. The transitions applied on relief panels are adjusted to the way of walking in pradaksina which requires the audiences to walk clockwise. By walking in pradaksina, the audiences can see the scene which depicts Ramayana and his army cross over the bridge towards Alengka kingdom. The position of the scene is at the end of the relief panels of Shiva temple, in which the audiences are asked to end the reading. The image that disappear little by little, in the context of transition in film, is called fade out transition. The next story can be seen gradually when the audiences get into the area of the first story panel at Brahma temple. Thus, the drawing way used in the story relief sculptures in Prambanan temple complex can basically used in various visual works for instance photography, film, paintings, etc.

\section{Reference}

Adisasmito, Nuning Damayanti.(2007). Transformasi Wujud Visual dan Penggayaan Gambar Ilustrasi Jawa Periode 1800 - 1920. Bandung: Disertasi ITB.

Hermanu, (2012). Relief Ramayana Candi Prambanan 1926-2012. Yogyakarta: Bentara Budaya.

Prasetya, Hanggar Budi. (2016). Rama sebagai Penjaga Kehidupan Relief Ramayana Prambanan. Journal “Kawistara".University of Gadjah Mada, Vol. 6 No. 3.

Setiawan, Pindi, (2012). Gambar Cadas Kutai Prasejarah: Kajian Kebutuhan Terpadu dan Komunikasi Rupa. Bandung: Disertasi ITB.

Tabrani, Primadi.(1991). Meninjau Bahasa Rupa Wayang Beber Jaka Kembang Kuning dari telaah Cara Wimba 
dan Tata Ungkapan Bahasa Rupa Media Rupa RunguDwimatra Statis Modern, dalam hubungannya dengan Gambar Pra Sejarah, Primitip, Anak dan Relief Cerita Lalitavistara Borobudur. Bandung: Disertasi ITB. . (2005 \& 2012). Bahasa Rupa. Bandung: Kelir.

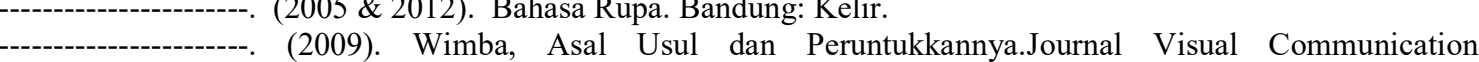
"Wimba".Bandung Instituteof the Technology.Vol. 1 No. 1.

Yudoseputro, Wiyoso. (2008). Jejak-jejak Tradisi Bahasa Rupa Indonesia Lama. Jakarta: Yayasan Seni Visual Indonesia dan Institut Kesenian Jakarta.

Yuliman, Sanento,(2001). Dua Seni Rupa. Bandung: Kalam.

Asep Deni Iskandar is currently a doctoral candidate at Insti tut Seni Indonesia (ISI) Surakarta and a Lecturer of Department of Desain Komunikasi Visual at Universitas Widyatama. This journal is his first publication.

Rustopo is a senior lecturer of Postgraduate Program at Institut Seni Indonesia (ISI) Surakarta while years before starting his lecturer assistant work he has been an artist. His music in Karawitan is his main focus as an artist and ethnomusicology has become his area as a lecturer. He composes musics, writes articles, and publishing several books.

Dharsono is a senior lecturer of Postgraduate Program at Institut Seni Indonesia (ISI) Surakarta. He has conducted researches in area of culture as well as aesthetics as his focus interest. He published several books and modules. As a scientist, his research area covers tradition aesthetics to learn culture.

Timbul Haryono is a member of Dewan Pakar Komite Basa Jawi Pusat, Surakarta since 1991 and of Grup Kesenian Sekar Puri since 2000. His area of expertise is mostly in Classical Archeology. He is a senior lecturer of Postgraduate Program at Institut Seni Indonesia (ISI) Surakarta. 